\title{
NEW HOUSING SYSTEMS AND MARKETING OF TABLE EGGS ${ }^{1}$
}

\author{
Zlatica Pavlovski, R. Cmiljanić, Zdenka Škrbić, M. Lukić
}

Contents: Intensive industrial production of table eggs applied numerous strategies in order to create product of special quality and known origin and it didn't only product for the market - egg of standard quality. New production systems were first applied in countries of European Union and later also in other developed countries there, objective was to satisfy the needs and requests of consumers of eggs with known origin.

Monitoring or tracing of food is new and modern discipline in food marketing. In light of food safety and possible bio-terrorism, each consumer is entitled to know every detail about the product that is consumed. Monitoring is no trick but more investment in safety system.

New systems of production of table eggs, marketing and systems for monitoring of egg on their way to consumer and other way around from consumer to producer will be presented in this paper.

Key words: Production of eggs, new systems, marketing, monitoring and tracing of eggs

\section{Introduction}

Intensive, industrial egg production has very interesting development over last 20 years. Egg as feed stuff was unfairly accused of being harmful to human health. However, in recent years, this injustice is slowly corrected (Hunton, 2004).

The fact that new organism is formed from the egg - chicken, is confirmation that egg is ideal feed stuff rich with nutritive substances. Egg is source of protein of the highest quality and it has unique combination of fatty acids which are necessary for human organism and these facts are used in promotion of egg as product of extremely rich nutritive composition and content.

Although $75 \%$ of total world production of eggs is performed in cage system with different housing density, in developed countries of the world considerable amounts of money are invested in new systems for housing of layers. Many participants in the chain of production of table eggs have developed serious marketing of production and sale of eggs, in accordance with new legislative regulations of European Union (directives) relating to poultry welfare, aiming to increase the consumption of table eggs (Pavlovski, 2004).

New systems in housing of poultry (improved cages, free range, semi-intensive system, deep litter, aviary system, organic production, etc.) provide primarily welfare of layers rather than improve the quality of table eggs. Considering that in countries of EU $92 \%$ of layers are still housed in cages it is normal to expect considerable decrease of egg production when new regulations/directives relating to minimum floor space per bird come into effect. Decrease of egg production in EU countries will result in decrease of profit, increase of price and reduction of number of employees.

Increased cost of alternative productions and at the same time of retail price of eggs from such production systems will certainly have effect on the decision of consumers regarding purchasing of this product. Question is whether the consumers are ready to pay higher price for poultry welfare or special guaranteed quality of eggs. Most of the polled consumers consider safety and freshness when purchasing eggs. Production system is also factor influencing the preferences of consumers, in other words entire concept which includes farm conditions, poultry welfare, nutrition, health condition, size of flock, etc. There are two categories of consumers, "citizen of the world" willing to pay more for specific product and the other category "consumer" who is expressing his concern about the production system but is not willing to pay more for such products.

Monitoring and tracing of food is new modern discipline in production and marketing of food. In light of food safety and possible bio-terrorism, each consumer is entitled to know every detail about the product he is consuming. Tracing is no trick, but more investment in safety system.

New systems of production of table eggs, marketing and systems for monitoring of egg on their way to consumer and other way around from consumer to producer will be presented in this paper.

1 Review paper supported by the Ministry of Science and Environment Protection, Project no. TR6885B - Revijalni rad je finansiran od strane Ministarstva za nauku i zaštitu životne sredine Projektom broj: TR6885B

2 Dr Zlatica Pavlovski, scientific counselor, dr Ratimir Cmiljanić, scientific counselor, mr Zdenka Škrbić, research assistant, mr Miloš Lukić, research assistant, Institute for Animal Husbandry, Belgrade-Zemun 


\section{New systems in production of table eggs}

Today, in production of table eggs, the cage system is mainly present or as it is popularly known as "non-improved cage" and over $90 \%$ of layers of table eggs are housed in this system. New regulations of the European Union determine the minimum of $550 \mathrm{~cm}^{2}$ of floor space per bird in cages. This minimum standard has to be applied until 2012 when battery system in poultry housing will completely be prohibited. It is expected that application of this directive will lead to considerable decrease in production of table eggs in EU and induce import of eggs from non-member states. Decrease in production of table eggs will result in reduced profit and number of employees. On the other hand, non-member states which are not in position to comply with these regulations and standards in housing of layers, due to lower production costs and higher production have opportunity to increase the sale of table eggs on EU market. Globally, application of new directives will have no general effect on improvement of poultry welfare, it will cause regionalization of the problem.

Production of table eggs used numerous strategies in order to create products of special quality and known origin (brand egg). New production systems have developed first in EU countries and later in other developed world countries aiming to provide poultry welfare and satisfy the requests of consumers of eggs of special and guaranteed quality. This relates first of all to eggs from free range, eggs from semi-intensive system, eggs from deep litter and improved cages which provide primarily poultry welfare. On the other hand, improved/enriched eggs appeared on the market, eggs enriched with omega 3 fatty acids, selenium, certain vitamins, etc. which satisfy specific demands of certain consumers. Eggs from organic production are specific since it is still not confirmed that these eggs have better quality than conventionally produced table eggs, however they have certain place on the EU market.

Many participants in the chain of table egg production have developed serious strategy of production and marketing of eggs based on new regulations of European Union relating to poultry welfare, origin of eggs and consumer opinions (Magdelaine and Mirabito, 2003; Horne and Tucken, 2004; Flock and al., 2001; Pavlovski et al., 2001; Pavlovski at al., 1997; Bloch, 2003). Freshness and safety of product are still two main criteria for purchasing of table eggs, however production system as one of the important factors is also considered by consumers when purchasing the products.

Comparative investigation of different production systems ant their effect on egg quality was research topic of many researchers and obtained results are very different. In spite of numerous researches there are no conclusions in favour of any system of poultry housing whether in relation to production results or egg quality (Varga, 1999). Advantages and disadvantages are present in every system, but it is obvious that in alternative systems the welfare of layers is improved. Effect of housing system for layers on egg quality is minor, but presence of dirty eggs and microbiologically contaminated egg shell is higher in alternative systems (Pingel and Jeroch, 1997). Gittins and Overfield, 1991.) Sauver, 1991, established that there was no difference in quality of egg white expressed in HU between eggs from cage and free range system. In recent researches of the effect of housing system on production results and egg quality, in accordance with new regulations of European Union banning the cage system and regulating the standards for floor space per bird in cages, there are also opposite results which will be stated in this paper. Hidalgo and Rosi, (2003) haven't determined any significant effect of housing system on egg quality and Abrahamsson and Tauson, (1995) between quality of eggs from cage and aviary system. In two recent papers the quality of egg white (HU) was compared in eggs from cage, aviary and free - range system: in the first paper, better quality of egg white was established in eggs from aviary system (Leyendecker et al., 2001), and in the other paper by Pavlovski et al., (2001) the authors have established better quality of egg white from free-range system. Mallet at al., (2003), investigated quality of egg shell of eggs from improved cages and cage system and established higher percentage of dirty, cracked and eggs contaminated with bacteria, also that egg shell thickness was greater in eggs from improved cages. Lower egg mass and better quality of eggs in aviary system compared to battery system was established by Horne, (1996). Tauson, $(2003,2004)$ compared the percentage of dirty and cracked eggs in several models of improved cages and established that there is difference between investigated models, but percentage of dirty and cracked eggs was lower than in any other alternative housing system for poultry. Quality of eggs was superior in layers housed in cages. Patterson et al. (2001) determined that eggs from layers fed only plant diet had $65.9 \mathrm{HU}$, eggs from layers from system respecting the poultry welfare 62.2 $\mathrm{HU}$, eggs from layers fed non-standard diet $61.2 \mathrm{HU}$, fertilized eggs $61.2 \mathrm{HU}$ and organic eggs $57.6 \mathrm{HU}$. 
Research in our country. In our country, the research of the quality of eggs from layers housed in different systems started in 1967. Results of investigation of exterior and interior quality traits of eggs from conventional battery system, free-range system, deep litter and aviary system are presented in table 1 . It can be concluded from data presented in table 1 that eggs from free range system had the best interior quality of egg white expressed through albumen height and HU and most intensive yolk colour.

\section{Marketing strategy and consumer reaction}

It is well known that in every production chain, the most important link is the final one - consumer. For each production, even production of table eggs, it is very important to know why consumers are purchasing specific product and what preferences consumers have in relation to that product. It is paradox that poultry production in many countries of the world, even in Serbia, over the period of several decades, has developed suddenly and become industrialized - revolution in livestock production, but almost no attention was directed to researches of consumer demands and marketing strategies. Even in countries with developed poultry production, first among few researches of the consumer relations to poultry products appeared in late sixties. However, in eighties these researches became very up-to-date and intensive, today on poultry scientific meetings researches of consumer attitudes and marketing strategies are given outstanding position. Favourable circumstance is that in our country considerable attention was directed to researches of the consumer relation to poultry products. Numerous researches directed in various directions have been carried out (Pavlovski et al., 1981b; Pavlovski and Mašić, 1993, 1994; Pavlovski et al., 2002b). It is interesting to mention that in year $198170,6 \%$ of questioned consumers thought that battery system was acceptable as production method, and one decade later this percentage was reduced to $54,6 \%$, and two decades later to $35,6 \%$. During this period the percentage of consumers in favour of banning of cage system almost doubled from $6,4 \%$ to $10,3 \%$ and $13,2 \%$, respectively. In mentioned research years number of consumers which were willing to pay higher price by $10 \%$ for eggs of guaranteed and controlled quality or from free-range system increased from $46 \%$ to $63 \%$ and $71,5 \%$. Obviously, number of consumers adherent of the free-range and banning of battery system on Belgrade market increased considerably which is in accordance with similar trends and new directives of EU.

Traceability is an indispensable part of any market and represents new and very up-to-date discipline in production and marketing of the food. In light of food safety and possible bio-terrorism, each consumer is entitled to know every detail about the product he is consuming. Recently, this novelty focused on tracing of eggs on their way from producer to consumer and the other way around. System was introduced in order to trace the origin of contamination and necessary transport conditions and prevent spoiling of the product and decrease of the quality of product on the way from producer to the consumer. Traceability is mainly introduced in order to provide necessary information about the product, for instance country of origin, complying with the requirements relating to poultry welfare, production system, genotype, quality traits of eggs, etc.

Traceability is no trick but investment in safe production system and marketing of the product. Producers have voluntary designed the tracing system; application of this system gives them complete insight into journey of eggs from producer to consumers and back to farm and processing plant. However, traceability of the product is only one segment in supply management or system of control of the quality and safety of the product.

International Organisation for Standards - (ISO) which developed international standards on voluntary basis for products and services defines traceability as possibility to trace the history, search and locate problems which are being experienced.

\section{Conclusions}

Based on presented data from our research as well as similar research carried out in the world, it is obvious that eggs are feed stuff preferred by many consumers. The fact that everything on the market finds its buyer and consumer was in it self kind of practical investigation of the wishes and demands of consumers. However, with further development of poultry production and its greater diversification, research of habits 
and preferences of consumers will become increasingly important, and results of such researches will be required for development of new technologies and production programmes and marketing of eggs (Pavlovski et al., 1996).

Trend of decrease of number of consumers who prefer eggs in their nutrition certainly demands attention and need to carry out investigation in order to determine the cause. Is it the consequence of cholesterol phobia, serious heart diseases or other reasons? In any case, producers of table eggs with marketing teams need to find adequate measures in order to stop further decrease of egg consumption and restore consumers who preferred eggs. Also, application of production programme and marketing of eggs of specific quality should provide for consumers new product of guaranteed and controlled quality (brand egg).

\title{
NOVI SISTEMI PROIZVODNJE I MARKETINGA KONZUMNIH JAJA
}

\author{
Zlatica Pavlovski, R. Cmiljanić,Zdenka Škrbić, Miloš Lukić
}

Rezime

Intenzivna industrijska proizvodnja kinzumnih jaja primenjivala je mnoge strategije u cilju stvaranja proizvoda posebnog kvaliteta i poznatog porekla i nije samo stvarala robu za tržište - jaje standardnog kvaliteta. Novi sistemi proizvodnje prvo su počeli da se primenjuju u zemljama Evropske Unije, a kasnije i u ostalim razvijenim zemljama u svetu radi zadovoljavanja zahteva potrošača za jajima sa poznatog brenda.

Praćenje hrane ili biti na tragu je nova i veoma aktuelna disciplina u marketingu hrane. U svetlu sigurnosti hrane i mogućeg bio-terorizma, svaki potrošač ima pravo da zna svaku pojedinost o proizvodu koji konzumira. Praćenje nije nikakav trik, već investiranje u bezbednosni sistem.

U radu će biti prikazani novi sistemi proizvodnje konzumnih jaja, marketing i sistemi praćenja jaja na putu do potrošača i obrnuto od potrošača do proizvođača.

Ključne reči : Proizvodnja jaja, novi sistemi, marketing, praćenje i trag jaja

Table 1.Some characteristics of eggs produced in different housing systems

\begin{tabular}{|c|c|c|c|c|c|c|c|c|c|c|c|c|c|c|c|c|}
\hline \multirow[t]{2}{*}{ Characteristics } & \multicolumn{2}{|c|}{$\begin{array}{c}\text { Žigić et al. } \\
1967\end{array}$} & \multicolumn{2}{|c|}{$\begin{array}{c}\text { Pavlovski et } \\
\text { al. } 1981 \mathrm{a}\end{array}$} & \multicolumn{2}{|c|}{$\begin{array}{c}\text { Pavlovski } \\
1982\end{array}$} & \multicolumn{2}{|c|}{$\begin{array}{l}\text { Pavlovski } \\
\text { and Mašić } \\
1986\end{array}$} & \multicolumn{3}{|c|}{$\begin{array}{c}\text { Mašić and } \\
\text { Pavlovski } \\
1994\end{array}$} & \multicolumn{3}{|c|}{$\begin{array}{c}\text { Pavlovski et al. } \\
2001\end{array}$} & \multicolumn{2}{|c|}{$\begin{array}{c}\text { Pavlovski et } \\
\text { al. 2002a }\end{array}$} \\
\hline & $\mathrm{I}$ & II & I & II & I & II & I & II & $\mathrm{I}$ & II & III & I & IV & III & $\mathrm{I}$ & II \\
\hline Egg m & 63.0 & 62.8 & 57.7 & 59.4 & 66.3 & 59.6 & 64.4 & 57.5 & 63.1 & 62.2 & 61.3 & 63.7 & 62.5 & 61.2 & 67.7 & 60.7 \\
\hline Shape index, \% & 75.1 & 74.1 & 73.6 & 74.6 & 75.4 & 74.1 & 75.8 & 73.2 & 76.2 & 76.3 & 75.5 & & & & 76.0 & 73.5 \\
\hline $\begin{array}{l}\text { Shell colour, } \\
\text { points }\end{array}$ & .51 & 2.94 & 3.69 & 3.58 & 3.30 & 3.00 & 3.16 & 3.02 & 3.72 & 3.49 & 3.41 & 3.61 & 3.45 & 3.36 & 3.55 & 3.41 \\
\hline $\begin{array}{l}\text { Albumen height, } \\
0.1 \mathrm{~mm}\end{array}$ & 51.3 & 59.9 & 49.9 & 56.2 & 47.3 & 56.4 & 72.6 & 77.6 & 70.0 & 64.1 & 66.1 & 77.2 & 77.1 & 77.3 & 72.6 & 77.6 \\
\hline Haugh Unit & 66.6 & 73.9 & 66.7 & 71.6 & 60.6 & 70.2 & 82.6 & 88.1 & 79.8 & 75.9 & 78.2 & 85.5 & 84.8 & 87.2 & 82.5 & 88.0 \\
\hline $\begin{array}{l}\text { Yolk colour, } \\
\text { Roche }\end{array}$ & 4.83 & $7.00^{*}$ & 9.44 & 13.6 & 8.80 & 11.0 & 9.74 & 12.8 & 9.84 & 9.98 & 10.2 & 10.5 & 10.3 & 11.2 & 9.74 & 12.6 \\
\hline $\begin{array}{l}\text { Shell thickness, } \\
0,1 \mathrm{~mm}\end{array}$ & & & 31.9 & 34.6 & 36.0 & 34.3 & 35.1 & 32.7 & 35.5 & 35.8 & 36.7 & 37.2 & 37.7 & 36.2 & 35.1 & 32.7 \\
\hline
\end{tabular}

I - cage , II - free-range, III - deep litter, IV - aviary

* - intensity of yolk colour, graded1-12, was determinedby comparosion with the colour of varying contrentracion of potassium bichromate solution $(0.5-20 \mathrm{mg} / \mathrm{mlwater}$ in tubesR $5 \times 16 \mathrm{~mm})$.

\section{References}

1. ABRAHAMSSON P., TAUSON R. (1995): Aviary system and convencional cages for laying hens. Acta Agric.Scand. Sct.A.Animal Sci. 45,191-203.

2. BLOCH M. (2003): EU organic poultry production after the EU regulation on organic livestock production. $X^{\text {th }}$ Europian Symposium on the Quality of Egg and Egg products. September, Ploufragan, Proceedings, 23-28. 
3. FLOCK D.K., PRESINGER R., SCHMUTZ.(2001): Egg quality- a challenge for bredders of laying hens. IX Europen Symposium on the Quality of Eggs and Egg Products, September, Kusadasi, Proceedings, 131-137.

4. GITTINS J.E., OVERFIELD N.D. (1991) : The nutrient content of eggs in Great Britan. $4^{\text {th }}$ Europian Simposium on the quality of Eggs and Egg products, May, Dorwerth. Proceedings, 113-121.

5. HIDALGO A., ROSSI M. (2003) : Influence of alternative housing system on table egg quality. $\mathrm{X}^{\text {th }}$ Europian Simposium on the Quality of Eggs and Egg Products, September, Ploufragan. Proceedings, 993-1000.

6. HUNTON P. (2004): Twenty years of exciting egg issues. World Poultry, 10, 26-27.

7. HORNE P.L.M. VAN (1996): Production and economical results of comercial flocks with white layers in aviary systems and battery cages. British Poultry Science,37, 255-261.

8. HORNE P.L.M. VAN, TACKEN G.M.I. (2004) : Market needs for higher quality eggs and egg products. XXII World' s Poultry Congress, June, Istanbul, Proceedings on CD .

9. LEYENDECKER M., HAMANN H., HARTUNG J., KAMPHUESJ., RINGC., GLUNDERG., AHLERS C., SANDER I., NEUMANN U., DISTL O. (2001): Analysis of genotype-enviroment interactions between layer lines and hen housing system for performance traits, egg quality and bone breaking strength. $2^{\text {nd }}$ communication. Zuchtungkunde, 73,4,308-323.

10. MAGDELAINE P., MIRABITO L. (2003) : Changes in demand for eggs and egg products and influence of changes in welfare regulations. $X^{\text {th }}$ Europian Symposium on the quality of Eggs and Egg products, September, Kusadasi, Proceedings, 34-45.

11. MALLET S., AHMED A., GUESDON V., NYS Y. (2003) : Comparision of eggshell and hygiene in two housing system / standard amd furnished cages. $\mathrm{X}^{\text {th }}$ Europian Symposium on the quality of Eggs and egg products, September,Ploufragan, Proceedings, 1001-1005.

12. MAŠIĆ B., PAVLOVSKI Z. (1994): Mala jata kokoši nosilja u različitim sistemima držanja. Monografija, Beograd, Naučni institut za stočarstvo.

13. PATTERSON P.H., KOELKEBECK K.W., BELL D.D., CARREY J.B., ANDERSON K.E., DAREE J. (2001) : Egg marketing in national supermarket: specialty eggs-Part 2. Poultry Science 80, 390-395.

14. PAVLOVSKI Z. (1981b) : Rezultati ankete potrošača o potrošnji jaja i odnosu prema jajima kao prehrambenom proizvodu. Peradarstvo, 1, 6-7.

15. PAVLOVSKI Z. (1982) : Spoljašnje i unutrašnje fizičke osobine konzumnih jaja na beogradskom tržištu s posebnim osvrtom na način prodaje i odnosa potrošača prema jajima kao prehrambenom proizvodu. (doktorska disertacija). Poljprivredni fakultet, Sarajevo.

16. PAVLOVSKI Z. (2004) : Novi propisi EU - dobrobit živine - zahtevi potrošača. Živinarstvo, 8-9, 40-58.

17. PAVLOVSKI Z., CMILJANIĆ R., VRAČAR. (1997) : Marketing jaja i pilećeg mesa sa specifičnim osobinama kvaliteta. I Yugoslav International Congress on Animal Husbrandy. Biotehnologija u stočatrstvu, 3-4, 219-229.

18. PAVLOVSKI Z., CMILJANIĆ R., LUKIĆ M., ŠKRBIĆ. (2002a) : Uticaj sistema držanja kokoši nosilja na kvalitet i neškodljivost konzumnih jaja. Biotehnologija u stočarstvu,5-6, 121-127.

19. PAVLOVSKI Z., CMILJANIĆ R., LUKIĆ M., ŠKRBIĆ Z. (2002b) : Odnos potrošača prema živinskom proizvodima. Savremena poljoprivreda, 3-4, 211-214.

20. PAVLOVSKI Z., HOPIĆ S., LUKIĆ M. (2001) : Sistemi držanja kokoši nosilja i kvalitet jaja. Biotehnologija u stočarstvu,5-6, 197-203.

21. PAVLOVSKI Z., MAŠIĆ B., APOSTOLOV N. (1981) : Quality of eggs laid by hens kept on free range and in cages. 4th Europian Symposium on the Quality of Eggs and Egg products, May, Doorwerth. Proceedings, II ,231-235.

22. PAVLOVSKI B., MAŠIĆ B. (1986) : Effect of free range and cage system on egg quality. 7th Europian Poultry Conference, Paris. Proceedings, 1326-1330.

23. PAVLOVSKI Z., MAŠIĆ B. ( 1993) : Consumer attitudes towwards eggs produced in different housing system. 5th Eoropian Simposium on the quality of Eggs and Egg Product, Tours, France. Proceedings, 30-36.

24. PAVLOVSKI Z., MAŠIĆ B.(1994): Odnos potrošača prema živinskim proizvodima. Živinarstvo, 7-9, $77-82$. 
25. PAVLOVSKI Z., MAŠIĆ B., CMILJANIĆ R., VRAČAR S. (1996) : Yugoslav program for the production and marketing of eggs of special quality. XXth World's Poultry Congress, August, New Delhi. Proceedings, 448-449.

26. PINGEL H., JEROCH H. (1997) : Egg quality as influenced by genetic, managment and nutritional factors. VII Europian Symposium on the quality of Eggs and Egg Products, September, Poznan. Proceedings, 13- 28.

27. SAUVER B. (1991) : Mode d'elevage des poules et qualité de l'ceuf de consommation. INRA Prod.Anim. 4 (2), 123-130.

28. TAUSON R. (2003) : Experiences of production and welfare in small group cages in Sweden. $X^{\text {th }}$ Europian Symposium on the Quality Eggs and Egg Products, September, Ploufragan. Proceedings, 980992.

29. TAUSON R.(2004) : Management and housing system for layers - effect on welfare and production. XXII World Poultry Congress. Proceedings on CD.

30. VARGA M. (1999) : Product quality and welfare indicators in laying hens. VIII Europian Symposium on the quality of eggs and egg products, Bologna. Proceedings, 249-275.

31. ŽIGIĆ LJ., MAŠIĆ B., MARINKOVIĆ V., ŠRAJBER L. (1967) : Prvi rezultati ispitivanja fizičkih osobina i unutrašnjeg kvaliteta jaja različitih provenijencija. Simpozijum ” Živinarski dani”, Portorož. Zbornik radova domaćih autora, 25-42. 